\title{
Transatlantica
}

Revue d'études américaines. American Studies Journal

$2 \mid 2017$

(Hi)stories of American Women: Writings and Rewritings / Call and Answer: Dialoguing the American West in France

\section{Courbet, Catlin, and the Exploitation of Native Americans}

\author{
Jane M. Roos
}

\section{(QpenEdition \\ Journals}

\section{Electronic version}

URL: https://journals.openedition.org/transatlantica/11062

DOI: 10.4000/transatlantica.11062

ISSN: $1765-2766$

Publisher

Association française d'Etudes Américaines (AFEA)

\section{Electronic reference}

Jane M. Roos, "Courbet, Catlin, and the Exploitation of Native Americans", Transatlantica [Online], 2 |

2017, Online since 13 May 2019, connection on 02 February 2023. URL: http://

journals.openedition.org/transatlantica/11062 ; DOI: https://doi.org/10.4000/transatlantica.11062

This text was automatically generated on 2 February 2023.

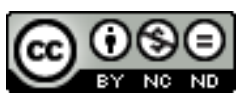

Creative Commons - Attribution-NonCommercial-NoDerivatives 4.0 International - CC BY-NC-ND 4.0 https://creativecommons.org/licenses/by-nc-nd/4.0/ 


\section{Courbet, Catlin, and the Exploitation of Native Americans}

Jane M. Roos

\section{Introduction: Courbet's The Painter's Studio and the} Theme of Exploitation

Figure 1

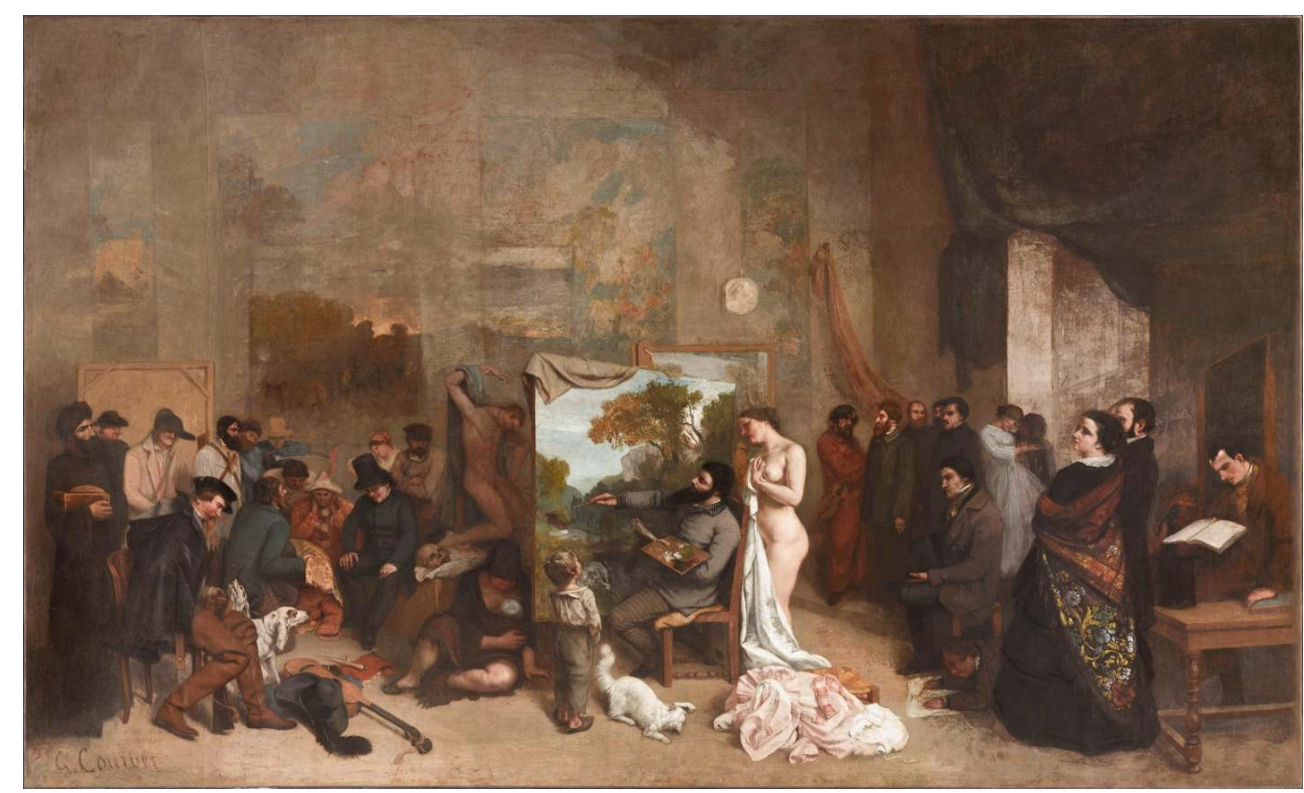

Gustave Courbet, L'Atelier du peintre, allégorie réelle déterminant une phase de sept années de ma vie artistique et morale, 1854-5. Oil on canvas, $361 \times 598$ cm., Musée d'Orsay, Paris. (c) RMN-Grand Palais/ Art Resource, NY

1 Gustave Courbet's L'Atelier du peintre (The Painter's Studio) (Figure 1) is arguably one of the most heavily dissected, deconstructed, and narrativized French paintings of the 
nineteenth century. And yet, as this essay proposes, broadening the inquiry to include transatlantic influences adds new levels of significance to the work's content and genesis. Bearing the subtitle a "Real Allegory Summing up Seven Years of My Artistic and Moral Life," the monumental canvas portrays the shift in Courbet's work that had begun in 1848. Much of the information about the painting comes from a letter to his friend Champfleury, in which Courbet established the mise-en-scène, adumbrated the general themes, and identified many of the figures (Courbet 121). However, as the paradoxical subtitle, a "real allegory," suggests, the painting juxtaposes descriptive and allusive modes of signification, so that not all the figures can be unequivocally determined.

2 At the center of the canvas, Courbet portrayed himself sitting in his studio in Paris; he is snappily dressed and flashes his "Assyrian" profile (Courbet 122). He holds palette, brushes, and palette knife and sits on a chair outfitted with a brightly colored cushion. ${ }^{2}$ Arced around him, as he touches a brush to a view of the Franche-Comté region of his birth, are a fleshy nude female, a young peasant boy in sabots, and a fluffy white, ballplaying cat.

On the right are depicted "the friends, the workers, the amateurs of the art world" (Courbet 121), the people who influenced and supported the direction of his Realist painting. Alphonse Promayet, a musician and childhood friend from Ornans, stands behind the nude, and he is faced by Alfred Bruyas, the artist's most significant patron. The socialist philosopher Pierre-Joseph Proudhon (born in Besançon) faces front, and he is joined by two more friends from Courbet's youth: Urbain Cuenot and Max Buchon, the latter important as a writer and collector of folk songs and tales. "Two lovers" are placed by a window, and sitting on a stool in front of them is Champfleury, another member of Courbet's circle with an interest in the art of the people. Alongside, a young boy lies on the floor drawing stick figures, and above him a woman wearing a brightly colored shawl stands beside a male figure whose features are barely visible. Courbet described the couple as "a woman of the world and her husband, [she] luxuriously dressed," and he ended his denomination of the right side with the figure of Charles Baudelaire, shown seated at the extreme right, with an open book in his lap (Courbet 122).

Figure 2

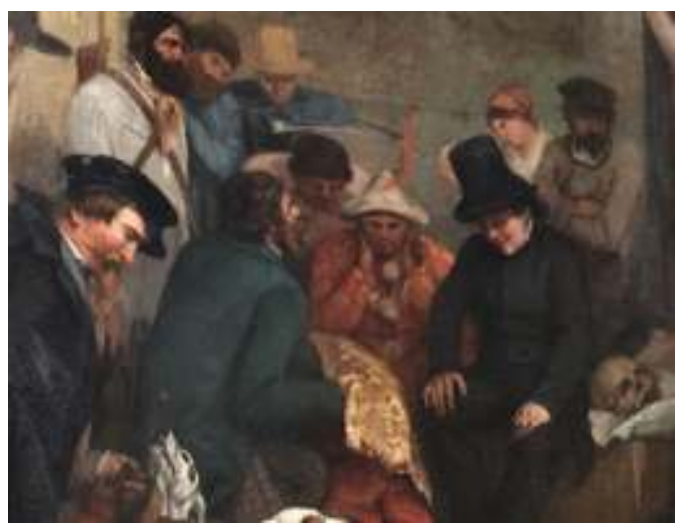

Detail of Courbet, The Painter's Studio, 1854-1855.

The left side of the triptych represents "the other world of commonplace life, the people, misery, poverty, riches, the exploited, the exploiters, the people who feed on 
death" ("les gens qui vivrent de la mort") (Courbet 121). These figures are not descriptive portraits, but generalized allusions to the agents and victims of suffering and exploitation. At the left edge "a Jew whom I saw in England" nearly occludes "the triumphant figure of a red-faced priest" (121). Next come a black-hatted figure clothed as a 1793 revolutionary, and "a hunter" with a gun strapped to his back. In larger scale, and abutting the hunter, sits "a poacher," holding a gun between his legs and accompanied by two hounds. Discernible in the background are a toque-hatted figure unmentioned in Courbet's letter to Champfleury and "a reaper," who leans on the blade of his scythe. In front of this figure, a "Hercules" bends toward a clownish figure that Courbet designated as a "queue-rouge," the latter wearing a triangular hat adorned with a red feather (Figure 2). A black-suited undertaker sits to the right, with his hands on his knees, and at his elbow, a skull rests on a Parisian newspaper. Facing the undertaker, a seller of used clothing offers "his rags" to the people around him. Two workers stand behind the undertaker, the female holding an infant barely visible behind the undertaker's tall, black hat. Next to the undertaker is a large studio model, of the type used by academic painters, and beneath the model, an Irishwoman dressed in rags huddles with a baby on the floor (121-122) (Figure 1). In a letter written to Louis Français around 1855, Courbet encapsulated the painting as follows: "It's the history of my studio what happens there morally and physically. It's quite mysterious, let anyone who can, figure it out" (124).

5 This essay focuses on the figures of Hercules and the queue-rouge, which have gone relatively unnoticed despite the slew of publications devoted to The Painter's Studio. ${ }^{3}$ An exception is the deeply thoughtful essay published by Hélène Toussaint in 1977, in which she trained her analytical lens on each of the painting's figures. Writing about the Hercules and queue-rouge, she posited that they were included in the painting "to attest to the commiseration that the XIX ${ }^{\text {th }}$ century showed toward saltimbanques. They are no longer the joyous acrobats ("joyeux bateleurs") of olden times but impoverished clowns ("pauvres paillasses") whose destiny is nothing more than misery and derision" (248). In keeping with the political program she ascribed to The Painter's Studio, she associated the figure of Hercules with Turkey and the French involvement in the Crimean War (254); and she posited the queue-rouge as symbolic of China, where France had recently "acquired a concession in Shanghai" (255). At the time she scrutinized the painting, some forty years ago, she noted that Hercules' "ears are ornamented with sparkling pendants" which she interpreted as being "in the shape of crescents" (254). Though the crescent is one of the national symbols of Turkey, Toussaint gave no explanation for Courbet's representation of the crescent in the form of ear jewelry or for the presence of these earrings on a male figure. In making these attributions, she admitted that the subjects were highly unusual for Courbet: "these migrant performers are unique in the ceuvre of Courbet, who contrary to his contemporaries, was not interested in the world of spectacle" (248). This essay proposes that a more plausible explanation for the figures of Hercules and the queue-rouge can be linked to stage performances in Paris in 1845, which featured Native Americans and underscored their exploitation in the United States. 


\section{Catlin's Native American Exhibits in Paris}

George Catlin opened his Indian Museum in Paris at the end of May $1845 .{ }^{4}$ America's "first Wild West Showman" (Reddin 4), he had begun his career as a portraitist, but the crudeness of his technique found little success among the fledgling arts establishment in the United States (Dunlap, vol. 2 378; Truettner 14-15; Dippie, 1990 9-10; Dippie, 2002 58-61). He then decamped westward, and over a seven- or eight-year period (his accounts of these years vary), he painted Native Americans and scenes of their customs and everyday lives. Featured in the museum were more than five hundred of Catlin's western paintings, as well as thousands of Native American artifacts that he had collected during his trips, including a wigwam, jewelry, peace pipes, tomahawks, arrows, scalping knives, skulls, and clothing, some of the latter "fringed with scalplocks from their enemies' heads" (Catlin, 1848 vol. 2 248-296). But the main attractions of Catlin's "exhibits" were twelve members of the Iowa tribe (Figure 3), who performed twice a day, in the huge Salle Valentino. Well-skilled in publicity, Catlin advertised the show with posters and produced an illustrated brochure in French, which describes each of the tribes' members and explains their dress, customs, dances, and songs (Catlin, 1845). ${ }^{5}$

Figure 3

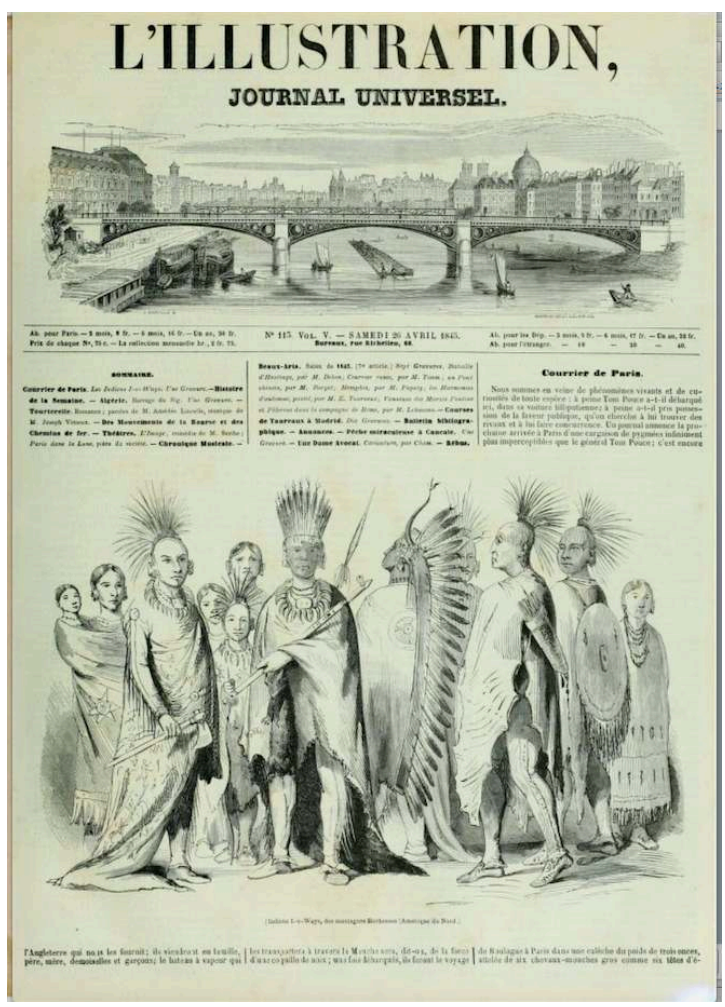

Indiens I-o-Ways, des montagnes Rocheuses (Amérique du nord), L'Illustration, April 26, 1845, 129. Collection of the Author.

7 By the time Catlin arrived in Paris, he had been touring his paintings and artifacts for more than a decade, first through cities in the United States and then through the British Isles (Reddin 9-26). For the London venue, he had brought with him two caged grizzly bears from the Far West, but when the nine-hundred-pound animals refused to 
adapt to captivity, he sold them to the London zoo, where they wasted away and died (Catlin, 1848, vol. 132-33). His next publicity-catcher was the hiring of British men and boys-the boys cross-dressed as women and girls-to impersonate Native Americans. While he lectured to the audience, the troupe enacted folksy "tableaux vivans" of tribal life in the west, which they animated with boisterous war-whoops, music, and song (Catlin 1848, vol. 1 95-97). ${ }^{6}$ In March 1844, he hooked up with the notorious P. T. Barnum, who had come to London on a tour with Tom Thumb. Dubbed "the Prince of Humbugs"-an epithet he loved-the shoddy, truth-bending marketeer specialized in hyperbole and occasionally outright hoax. ${ }^{7}$ Barnum arranged to have twelve members of the Iowa tribe brought from the United States, paid for their passage to London, and provided a security deposit of 300,000 francs to cover their return home (Sand, 1845 193; Barnum, 1855 345-346; Saxon 369, n. 3; Dippie, 1990 101-105). ${ }^{8}$ In his autobiography, Barnum noted that the Iowas "were exhibited by Mr. Catlin on our joint account, and were finally left in his sole charge" (1855 346). By mid-summer Barnum had reached an agreement with Catlin. Barnum thought that "Catlin \& self" would make "a large amount" of money, and two weeks later he could boast that "I now have got the Indians under full blast" (Barnum, 1983 27-28). After appearances in London, Catlin had taken the Iowas on a tour of the British Isles, during which two of the tribe members contracted tuberculosis and died-the "babe Corsair," son of O-kee-wee-me (The Female Bear Who Walks on the Back of Another) and Shon-ta-yi-ga (Little Wolf); and the beloved warrior No-ho-mun-ya (One Who Gives No Attention).

8 The Iowas arrived in Paris in a state of deep mourning (Catlin, 1848 vol. 2 170-171; 200-201), but they held to their bargain and performed. Catlin settled them into the Victoria Hotel, and while arrangements for the exhibition were underway, the group toured the city and were fêted by French dignitaries. On April 21, Louis Philippe received them in the Palais des Tuileries, as he had received Barnum and "Général Tom Pouce" a month earlier (Catlin, 1845 22-24; Barnum, 1855 99). "The King of the French" greeted the Iowas cordially, and speaking through their interpreter he recounted his time in the United States in the late 1790s, when he and his brothers had visited tribes from Buffalo to New Orleans and stayed in their wigwams (Catlin, 1848 vol. 2 212; Louis Philippe; Elliott 17-20). He introduced the Iowas to members of his family and presented the two main chiefs, Mew-hew-she-kaw (White Cloud) and Neu-mon-ya (Walking Rain), with gold medals featuring his image on the front. ${ }^{9}$ These, he promised, would be engraved with each of their names, and he would bestow silver medals, similarly engraved, upon the other members of the tribe (Catlin, 1848 vol. 2 212). Numon-ya, who was their War Chief and most eloquent speaker, expressed the tribe's gratitude and presented the king with strings of wampum and a bright blue peace pipe adorned with ribbons. After the ceremony, and to the astonishment of the king and his entourage, the Iowas began a vigorous performance of their tribes' traditional War Dance:

Nothing could have been more thrilling or picturesque than the scene [...] of this huge and terrible-looking warrior [Shon-ta-yi-ga], frowning death and destruction on his brow, as he brandished the very weapons he had used in deadly combat, and, in his jumps and sudden starts, seemed threatening with instant use again! The floors and ceilings of the Palace shook with the weight of their steps, and its long halls echoed and vibrated the shrill-sounding notes of the war-whoop. (Catlin, 1848 vol. 2 215) 
Figure 4

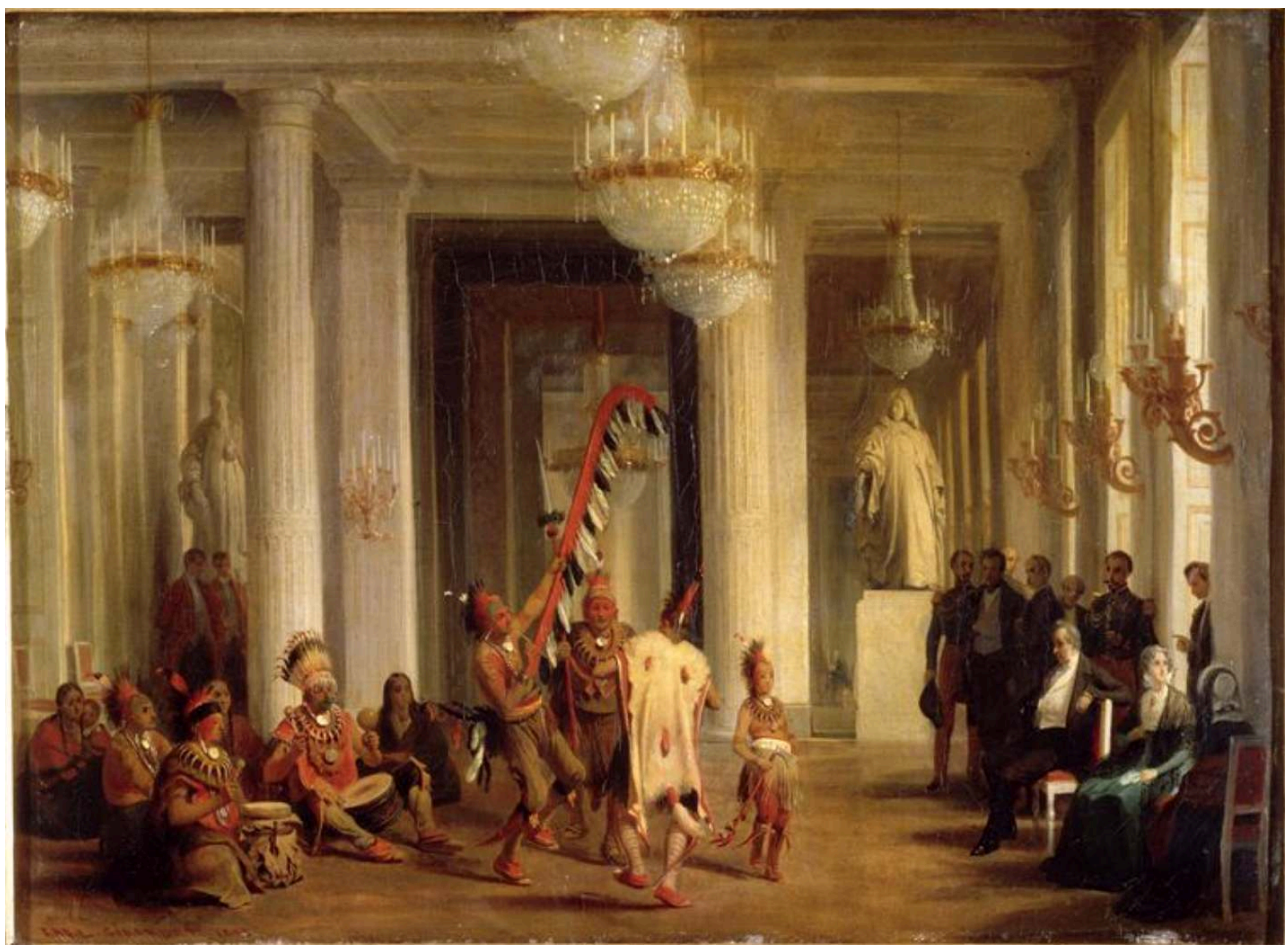

Karl Girardet, Le roi Louis Philippe assiste à une danse d'indiens lowas, dans le Salon de la Paix, aux Palais des Tuileries, 1846. Oil on canvas, $39 \times 53.5 \mathrm{~cm}$., Musée national des châteaux de Versailles et de Trianon. (c) RMN-Grand-Palais (Château de Versailles)/image RMN-GP/Art Resource, NY.

Karl Girardet's small oil (Figure 4) depicts the Eagle Dance that followed. Louis Philippe and his intimates are situated at the right, and Catlin stands by a window, explaining the ritual to Queen Amélie. On the left the drummers and singers sit on the ground, as was the Iowas' custom (Blaine 178), and in the center the Medicine Man, Se-non-ti-yah (Blistered Feet), holds an eagle whistle to his lips and wields a large standard hung with animal tails. He is accompanied by Shon-ta-yi-ga, Mew-hew-she-kaw, and the young Wa-ta-we-bu-ka-na (Commanding General). A rarity among depictions of the Iowas' stay in Paris, Girardet's highly finished canvas particularizes prominent features of the dancers' apparel: feathered headdresses, wampum and bear-claw necklaces, medals, ear ornaments, and buffalo-skin tunics in tones of orange and brown. However, missing from the image is a sense of the Iowas' ferociously energetic, often frightening, performance, which featured vigorous jumps and stomps and roaring war whoops and shouts. In their poses and facial features, Girardet's dancers are made to seem placid and restrained, as if intimidated by the opulence of the Palais des Tuileries and the alterity of European civilization. ${ }^{10}$

After their visit to the king, Catlin brought the Iowas to the Royal Academy of Sciences (Catlin, 1845 24), and in that reception they were stripped of their humanity and treated as anthropological specimens. On their arrival, they were "ushered and squeezed and pushed into a dense crowd of gentlemen, and [...] were gazed and scowled at, their heads and arms felt, their looks and capacities criticized like those of wild beasts." When they returned to their rooms, the Iowas expressed their unease about the members of that eminent group:

they recollected to have seen in some of their faces, while examining their heads and arms, decided expressions of anxiety to dissect their limbs and bones, which 
they now felt sure would be the case if any one of them should die while in Paris. The War Chief said that "he had been decidedly displeased, and the chief also, but it would be best to say no more about it, though if any of the party got sick, to take great care what physicians were called to visit them." (Catlin, 1848 vol. 2 225-226)

11 As Catlin described the performances in the Salle Valentino, a bell would sound and Mew-hew-she-kaw would lead the Iowas into the room, all of them "in full dress and paint, and armed and equipped as if for a battle field" (Catlin, 1848 vol. 2 228). Catlin would introduce them, and with a war-whoop that terrified the audience, they would begin their Discovery Dance, which mimed the sighting and capture of an enemy. The Eagle Dance would follow, and then a display of the tribe's archery and ball-playing skills and a final dance. Performance over, the Iowas would come forward and, seated on the floor, they would speak with the audience through their interpreter. After they returned to their quarters, Catlin had the audience to himself, which was a moment he relished: "I became the lion, and was asked for in every part of the rooms" (Catlin, 1848 vol. 2 231).

George Sand was in the audience for at least two performances, and her account of the experience conveys with immediacy the atmosphere, color, and sound. She wrote that the semi-nude dancers carried tomahawks and "lances garnished with human hair and teeth, and a sort of delirious fury seemed to transport them" when they launched into "raucous shouts, barks, howls, high-pitched whistling"(Sand, 1846 197). They wore headdresses of "eagle feathers or tufts of animal hair" (197), and their faces were brilliantly painted-some in "blood red," "others in a livid white, their eyes rimmed in scarlet, others in green and yellow, finally others half-red and half-blue or with the imprint of an azure hand on their naturally bronze skin" (197). Their bear-claw necklaces looked dangerously sharp, as if they were cutting the wearer's skin, and they wore coats made "of the hides of buffalos and of white wolves with tails ("queues") that float and seem part of the man." The music had a "muted, mournful sound," while the singers" "guttural, seemingly inhuman voices launched into muffled and rhythmical grunts" (197). As they enacted their rituals, she was seized by terror and broke out into a "cold sweat" (198). At one point she saw them as other-worldly "demons of the desert, more dangerous and relentless than the wolves and bears among which I would have willingly sought refuge" (198). When the dances ceased, and the participants greeted the audience, Sand was startled by their gentleness, and she determined to learn more about the Iowas, who despite the ferocity of their rituals and their custom of scalping, seemed au fond people of kindness and good will.

13 Sand's "Relation d'un voyage" appeared in Le Diable à Paris in early June $1845 .{ }^{11}$ She framed her essay in the form of two letters to a friend, and she opened with the image of an enfolded double voyage-from France to the new world via ship/from her apartment to the Salle Valentino via cab. Her account is stunning and compassionate and deserves to be better known by an Anglophone audience. Having conveyed a sense of the distances separating the Parisian metropolis from the isolated plains of the West, she recoded the stereotypical notions of savagery and civilization. She began by addressing the plight of the Iowas in the United States, and she described the misery and exploitation that had brought the race to near extinction. White settlers in America had invaded and seized Indian territory, and they had exposed the tribes to the deadly effects of small pox, gun powder, whiskey, and, as she phrased it, "other benefits of civilization" (Sand, 1846 187). According to her account, the Iowa tribe, 
which had once numbered six thousand had been brutally reduced to a third of that number ${ }^{12}$ and she questioned where the catastrophe would end:

What will be the outcome of this battle of extermination, in which the first advances of the savage are intemperance, a vast system of poisoning, the use of weapons more murderous than those of their fathers, and the destruction of game, their unique resource? The catastrophe that hounds them is horrifying to foresee, and when one thinks that the liberties so vaunted in the United States, and the absence of misery and abjection, which creates the appearance of Anglo-American society being so superior to our own, rests on nothing more than the fatal extinction of the first inhabitants, is one not profoundly saddened by this monstrous law of conquest [...]? (190)

To Sand, the Iowas' appearance in the Salle Valentino was yet another form of exploitation, this time at the hands of "the entrepreneur" (193). She compared their presentation to that of animals in a zoo, and she was "outraged that a king and his court, executing their sacred dances, were exhibited [...] on a makeshift stage, for the sum of 2 francs a head" (194). She thought that "these new Argonauts" did not understand the venue's connotation and that the crowd's whistling and tossing small change reduced the Iowas to the level of "saltimbanques." Did the audience think that paying the admission fee bought them the right to such insulting behavior? (194-95).

Figure 5

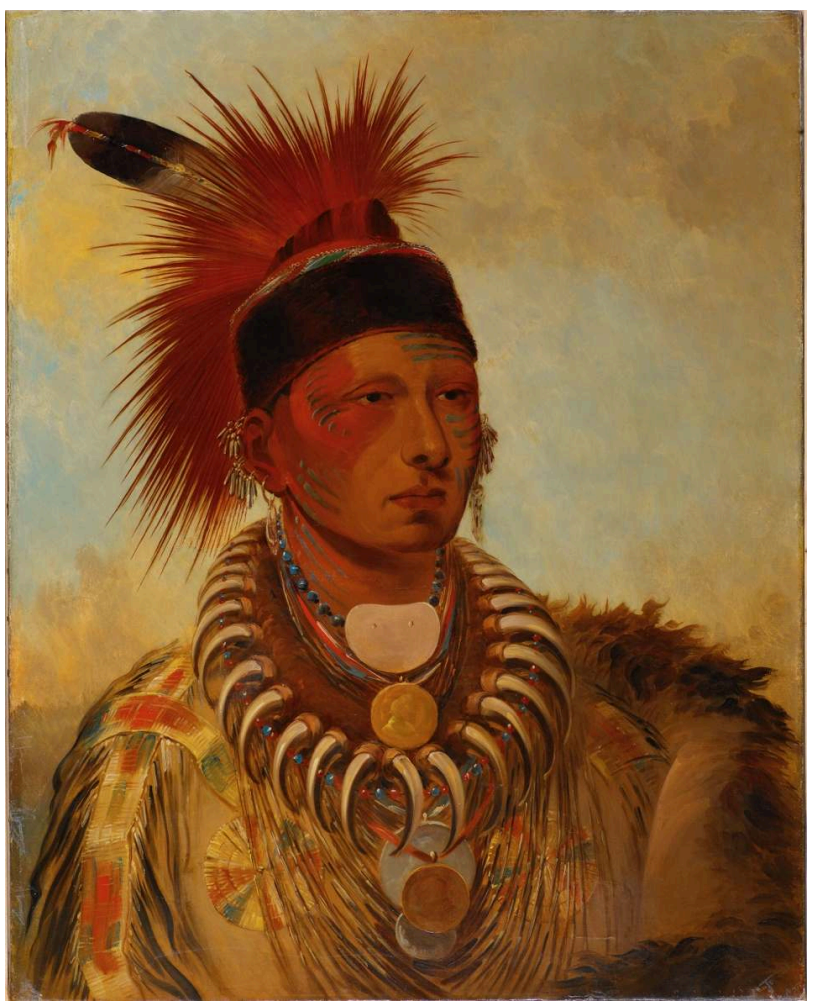

George Catlin, Portrait of Mew-hew-she-kaw (White Cloud), c. 1845, oil on canvas, 81 x $65 \mathrm{~cm}$., Musée du Quai Branly-Jacques Chirac, Paris. (c) Musée du Quai Branly-Jacques Chirac, RMN-Grand Palais/Art Resource, NY.

Sand returned to the Salle Valentino several days later and visited the Iowas in their living quarters. She spoke first with Mew-hew-she-kaw, chief of the Iowa nation (Figure 5), and his wife, Ru-ton-ye-wee-ma (Strutting Pigeon); and she presented them with a length of red fabric, "the most precious gift one can make to an Indian chief," 
and a necklace of beads (199). She then met each of the other Iowas in turn and gave everyone a welcoming gift. ${ }^{13}$ Shon-ta-yi-ga (Figure 6) was her favorite, "the person who most gained our friendship, despite the amiability of the doctor, despite the great wisdom of Walking Rain, and the beauty of his child, despite the gentle sadness of White Cloud, and the modesty of Her Majesty the queen" (201). Shon-ta-yi-ga and Okee-wee-me were still grieving for their son, Corsair, and although Sand had been terrified at first by the father's powerfully "Herculean appearance and sharply defined features," he now seemed to her "the gentlest and best of men" (201).

Figure 6

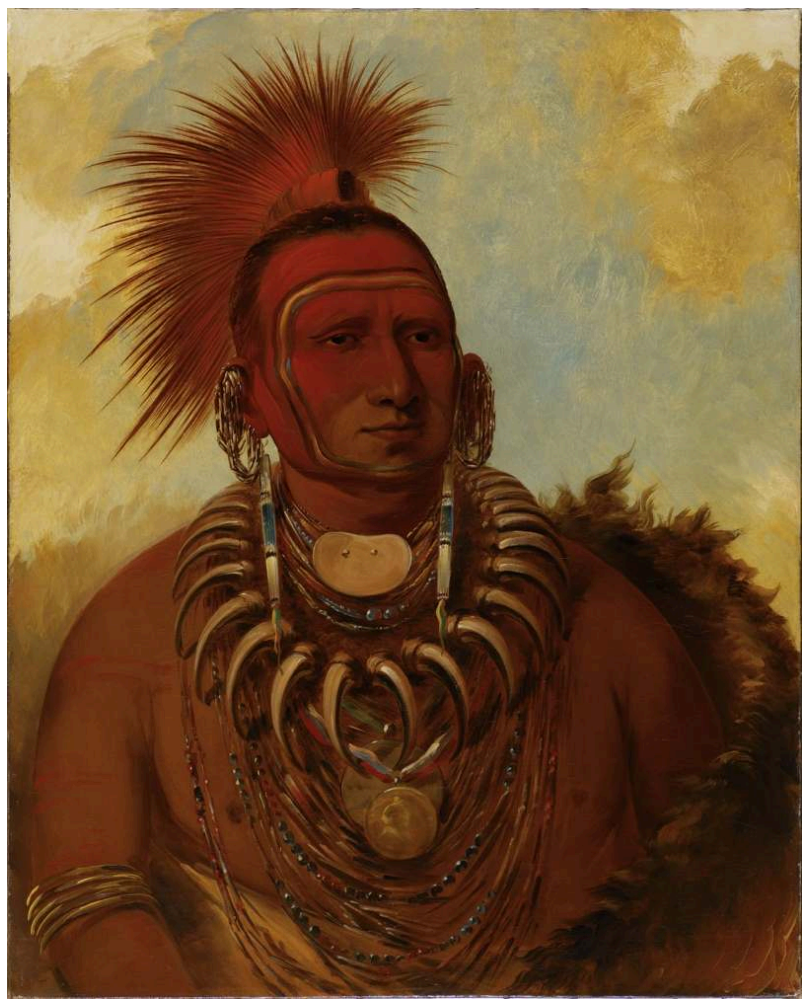

George Catlin, Portrait of Shon-ta-yi-ga (Little Wolf), c. 1845, oil on canvas, 81 x 65 cm., Musée du Quai Branly-Jacques Chirac, Paris. (c) Musée du Quai Branly-Jacques Chirac, RMN-Grand Palais/Art Resource, NY.

On June 13, little more than two weeks after the Iowas opened in Paris, O-kee-wee-me died from tuberculosis, the disease that had killed her son. On her deathbed, Catlin arranged for her to be given a Catholic Baptism, as well as the Last Rites ("Nouvelles et faits divers," 1845a), and after a funeral in the Église de la Madeleine, at which "a great number of the faithful and the curious had gathered" ("Nouvelles et faits divers," 1845b), O-kee-wee-me was buried in the cemetery of Montmartre. Devastated by her death, the Iowas packed their possessions and left for America within the week (Catlin, 1848 vol. 2 272-275). ${ }^{14}$

17 The final iteration of the Indian Museum ended in yet more Native American deaths. After the departure of the Iowas, Catlin showcased eleven Ojibwas from northern Canada, and as Brian Dippie has styled the group, "[ $t]$ hey were not a band of uncorrupted natives from the wilds of Canada, but a touring group organized by a welleducated former Methodist missionary, George Henry, who traveled under his Ojibwa 
name Maungwudaus or, as he translated it, Great Hero" (1990 108). Attendances at their performances dropped, and when Catlin's lease on the Salle Valentino expired, Louis Philippe had the collection moved to the Salle de Séance in the Louvre, and he commissioned copies of fifteen of Catlin's paintings (Catlin, 1848 vol. 2 285). In the fall, the Ojibwas' manager in London announced that he could no longer pay them nor fund their travel back to England. Catlin assumed responsibility and brought them to Brussels, hoping that several more performances would offset the costs of the trip. In Belgium two of the Ojibwas died from small pox, and five more of the troupe succumbed after their arrival in London (Catlin, 1848 vol. 2 292-303; Maungwudaus, 2006). Only four of the Ojibwas who performed in Catlin's Musée de l'Indien managed to survive their European ordeal. ${ }^{15}$

\section{Native Americans and Courbet's Hercules and Queue- Rouge}

As of this writing, I have been unable to uncover any historical documentation that specifically links Courbet's Hercules and queue-rouge directly to Catlin or to the Native Americans exhibited in his Museum. Not to be overlooked or diminished, however, is the visual evidence suggested by these figures and the serious attention given to Catlin and his museum by members of Courbet's intimate circle. These included Champfleury and Baudelaire, both of whom appear prominently in The Painter's Studio. According to the Dictionnaire Littré, the lexicographic authority of the second half of the nineteenth century, "Hercules" signifies the "name of a demi-god, son of Jupiter, and celebrated for his strength and his labors," as well as "a character from fairground spectacles, remarkable for his strength" (Littré 2008-2009). In relation to The Painter's Studio, Hercules' dual identity seems particularly fitting in that it could simultaneously reference the nobility of the Native American dancers-whose powerfully bare torsos led Sand, among others, to associate them with the classical figures such as Herculesand their vulgarization into common fairground types. ${ }^{16}$

Adjacent to Hercules is the figure Courbet identified as a queue-rouge, a term so obscure that it goes unmentioned in the Dictionnaire Littré. The website for the Centre national de ressources textuelles et lexicales characterizes "queue-rouge" as an old term for a "bouffon, paillasse," that is, a circus jester or fool. ${ }^{17}$ Courbet is known to have loved word play and puns (Toussaint 260-261), and his use of the unusual designation queuerouge, in preference to any of the more common terms for clown, has particular resonance for the Iowas and their dress. As Native Americans, they were sometimes given the offensive designation "peaux-rouges" (redskins). ${ }^{18}$ In addition, they featured vivid touches of "rouge" on their headdresses, faces, and garments; and they displayed "queues"-various animal tails and avian tail feathers-on their clothing, heads, and ceremonial objects (Figure 4). In the brochure accompanying his Indian Museum, Catlin noted that Iowa warriors "shave the entire head, except for the top, where they leave a small tuft called a scalp tuft; they attach to it a magnificent crest, made of hair from the tail ("queue") of deer and horse, and dyed red. From the center of this crest, which slightly resembles a Greek helmet, soars the feather of an eagle of war, which completes the coiffure of the warriors" (Figures 5 and 6) (Catlin, 1845 11). Whether Courbet purposely chose an obscure term for his clown, or conceived "queue-rouge" as a clever personal coinage, the appellation decontaminates "peau-rouge" by replacing 
the metonym "peau" (skin)-of the generic and offensive term-with the synecdoche "queue" (tail)-of specific relevance to the Iowas customary headgear and dress.

Figure 7

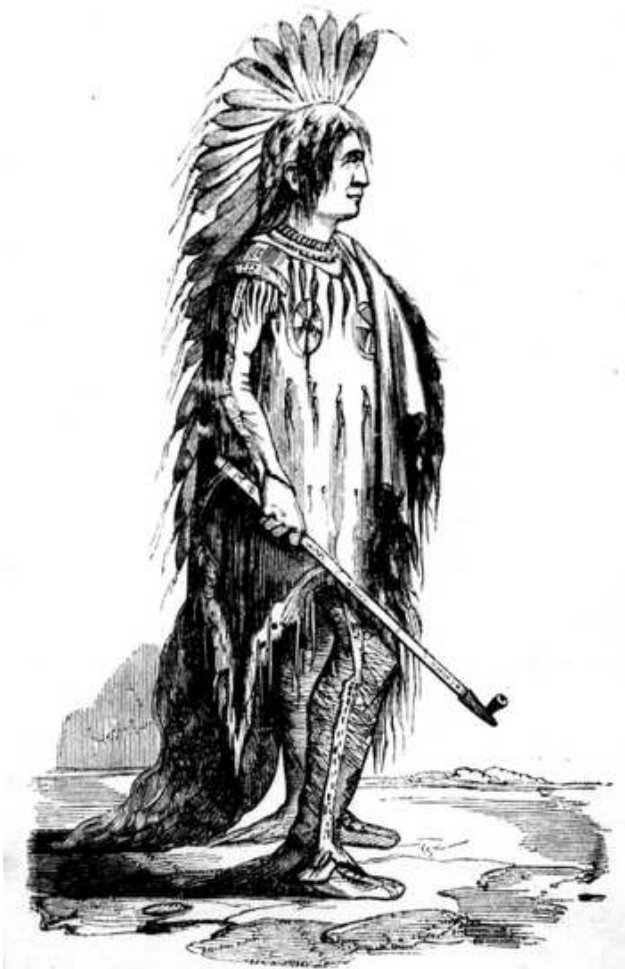

lowa Decorations, in Catlin 1845, [p. 7]. Collection of the Author. 
Figure 8

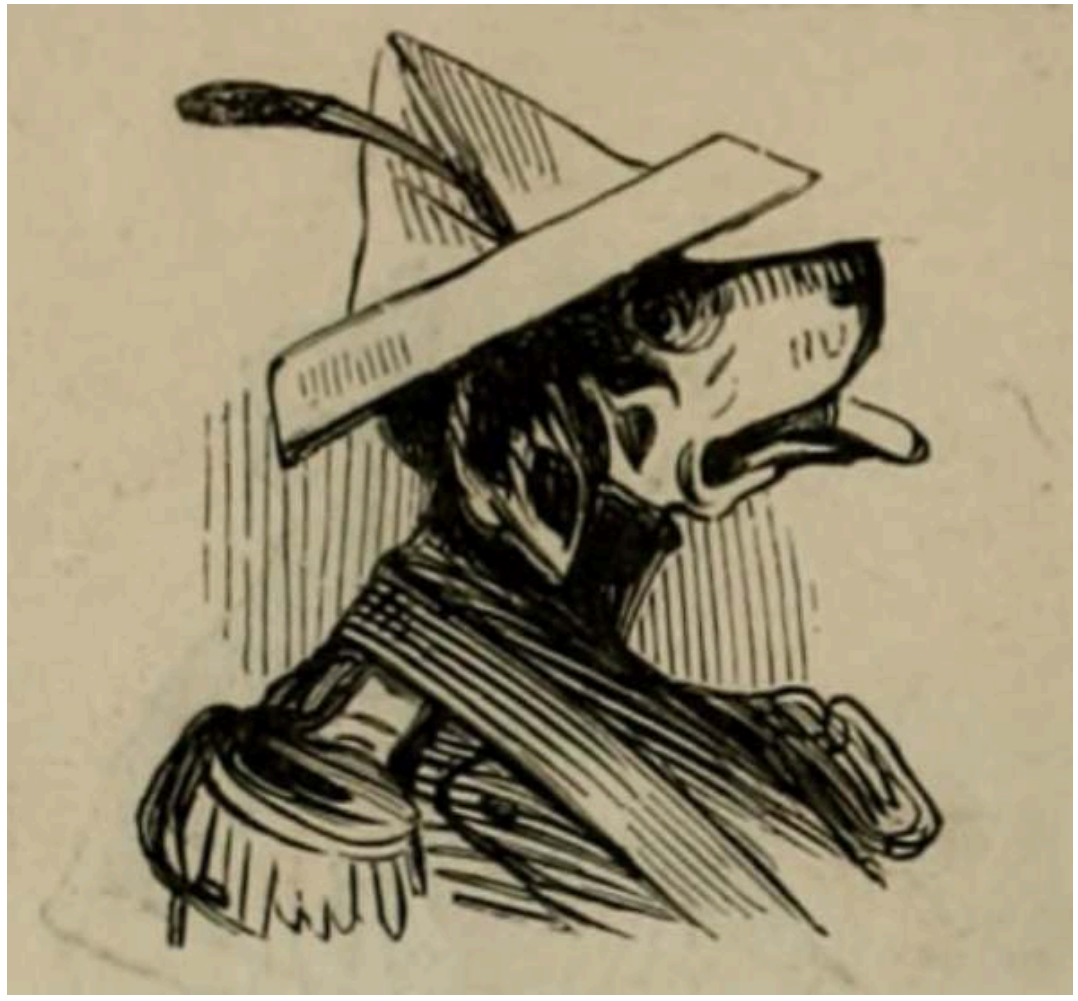

Image from Le Salon caricatural de 1846, p. 8. Collection of the Author.

Courbet's queue-rouge has the brownish skin tone seen in Catlin's portrayals of Native Americans. ${ }^{19}$ Strands of dark hair appear at both sides of its head, and although the Iowa warriors shaved their heads except for the scalp tuft, other of the tribal males kept their hair shoulder-length or longer (Figure 7). On the clown's head, Courbet depicted an odd triangular hat, which bears a slight resemblance to the headgear (sans feathers) of Honoré Daumier's later depictions of saltimbanques (Thomson Figs. 8-11, 13). Much closer in similarity is the feathered cocked hat that appeared in the Salon caricatural de 1846 (Figure 8), a collaborative publication in which Baudelaire was involved. ${ }^{20}$ The caricature satirized the portrait of an officer in the Corps Royal, by replacing the head with that of a dog and topping the dog with a silly and childish folded-paper hat (Baudelaire 1332). In relation to the queue-rouge, the triangular hat performs a similar function, and it implies the diminishment and infantilization experienced by the Iowas when they were exhibited in Catlin's museum. 
Figure 9

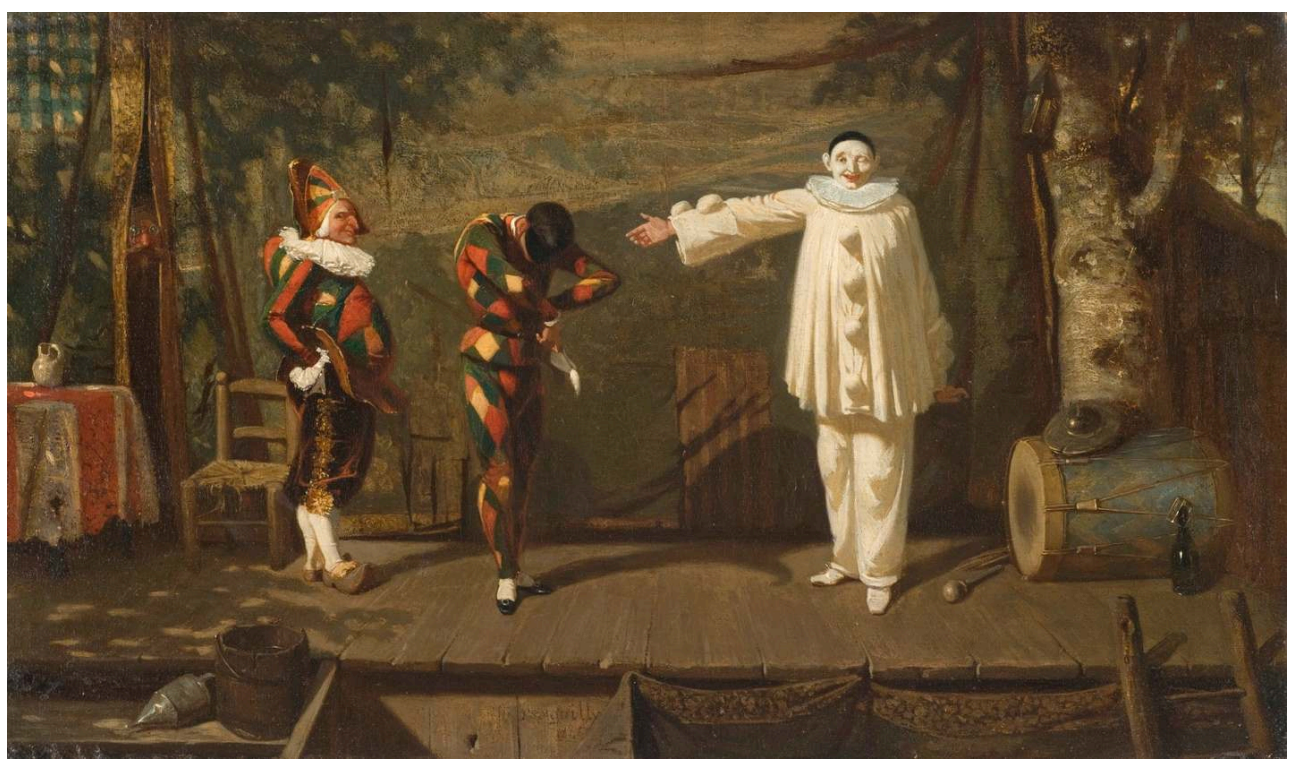

Octave Penguilly-L'Haridon, Parade: Pierrot présente à l'assemblée ses compagnons Arlequin et Polichinelle, 1846. Oil on canvas, 27 × 45.8 cm., Musée de Sainte-Croix, Poitiers.

Figure 10

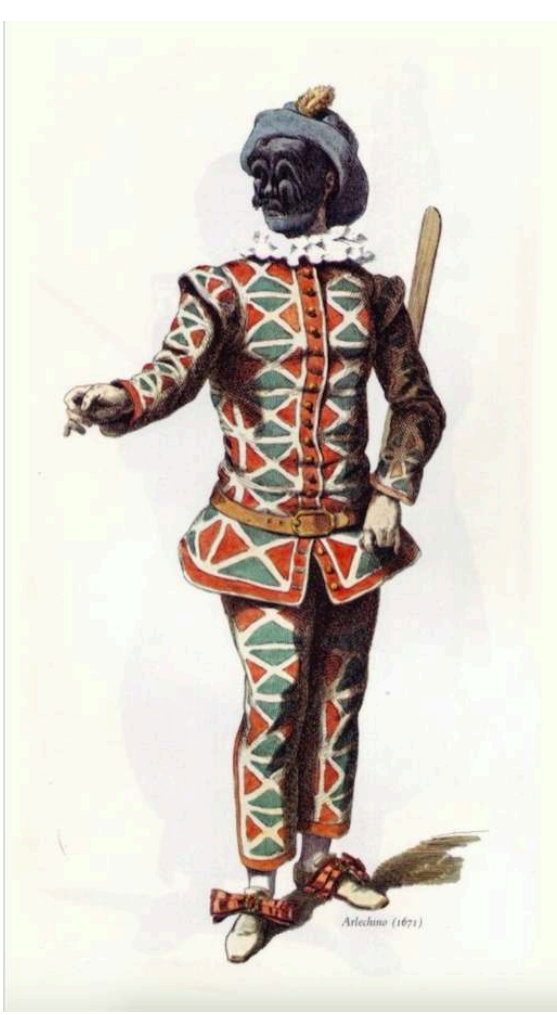

Maurice Sand, Harlequin, from Masques et bouffons, 1862, between pages 80 and 81 . Collection of the Author.

21 The patterning of the clown's jacket subjugates the brilliant color touches and linear patterning seen on the Iowas' buffalo-skin clothing (Figures 4 and 5) to straight-edged shapes that mark the European harlequin's costume. Examples of this clown type 
appear in Octave Penguilly-L'Haridon's Parade (Figure 9), shown at the Salon of 1846, and in an engraving from Masques et bouffons (Figure 10), written and illustrated by Sand's son, Maurice, who had accompanied her on her visits to the Salle Valentino. The three round shapes that decorate the chest of the queue-rouge similarly submit to an evocative double reading, as references to European clown culture and as prominent features of Native American dress: they can be interpreted as allusions to the pompoms that decorate the costume of a saltimbanque or Pierrot (Figure 9) and to the discs prominently displayed by Iowa males (Figures 4, 5, and 6). The topmost disc is the shell pectoral that was a characteristic accessory of the Iowas, and the lower discs represent the various medals "awarded" by representatives of the governing institutions to Native Americans they considered well behaved. Shon-ta-yi-ga (Figure 6), for example, is shown wearing a shell disc at his neck and two medallions below his bear-claw necklace-probably the bronze "Indian peace" medal (Figure 11) he was given during the presidency of John Tyler and the silver medal granted by Louis Philippe. ${ }^{21}$ Similar discs are seen in Girardet's depiction of the Iowas' performance (Figure 4) and in Catlin's Portrait of Mew-hu-she-kaw (Figure 5). Invisible now are the sparkles of paint around Hercules' ears that were mentioned by Toussaint in 1977. Inexplicable in relation to the clothing and ornaments of Asian or European males, these light-catching specks make sense as references to the glittering ear ornaments that were distinctive features of the Iowa warriors' adornments (Figures 5 and 6).

Figure 11

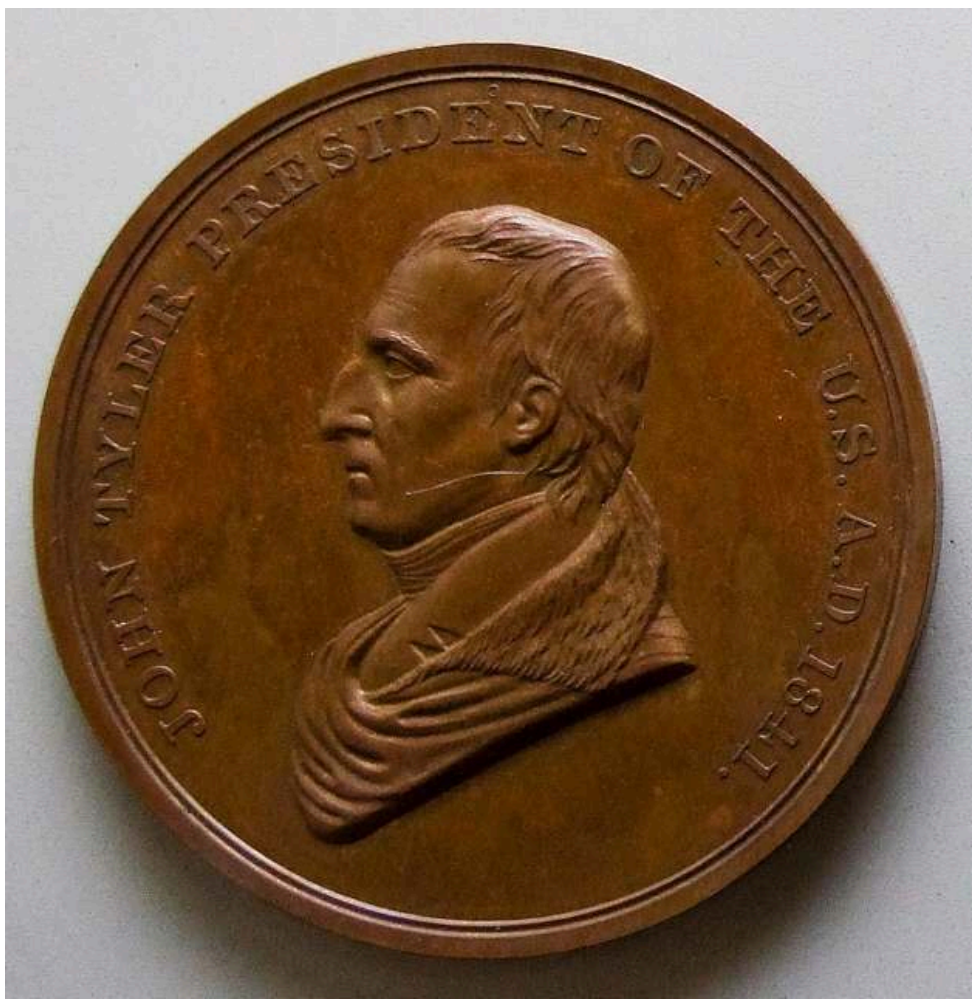

John Tyler Peace and Friendship Medal, 1841. Photograph courtesy of the Yale University Art Gallery.

The figures surrounding the Hercules and the queue-rouge reinforce themes of oppression and suffering (Figures 1 and 2). "Le faucheur," the scythe-wielding reaper at their backs, gains relevance as signifying the white man's clearing and usurpation of 
Native American territories and as evoking the topos of the Grim Reaper, indicative of the massive deaths caused by the invasion of white "civilization." The undertaker, to the right of the queue-rouge, alludes both to the near-extinction of Native Americans in the United States and to the lives lost during the Paris trip, those of the three Iowas and seven Ojibwas. The figure could also be a reference to P. T. Barnum, the person who funded the Iowas' trip to France and was blamed by Sand for their exploitation and debasement in the Salle Valentino. The skull at his elbow can also be seen to indicate the extinction of so many Native Americans and the deaths brought about by their importation to Europe, and with the knife at the undertaker's feet the scarifying artifacts-skulls, scalps, scalping knives-exhibited in the Musée Catlin.

Facing Hercules, the saltimbanque, and the undertaker is the seller of cheap, used clothing, which could refer to the Iowas' love of brightly colored material. Relevant to the implied transaction is a comment made by Sand concerning the seductive impact of the consumer culture dominant among whites in the United States and Europe: "The lure of profit is another source of devastation. The Indians have learned to exchange their animal skins for our products, and a tribe that does this and is close to civilized establishments, destroys in three days today more deer and bison for commerce than it had previously killed in a year for its own consumption." (Sand, 1846 190). The slaughter of so much game meant that these staples of the Native American diet were increasingly scarce.

\section{Reactions to Catlin's Museum and to His Paintings of the Far West}

The 2006 issue of the anthropological journal Gradhiva, entitled Du Far West au Louvre: le musée indien de George Catlin and published by the Musée du Quai Branly-Jacques Chirac, which now houses the paintings commissioned from Catlin by Louis Philippe, comprises an invaluable series of essays devoted to Catlin, his museum, and his paintings. The ideas put forth in several of the articles intersect with and help to reinforce my research on Catlin and Courbet. In "L'Éffet Catlin," written by the late Daniel Fabre, he theorized that Catlin's exhibits in Paris-the performances and tribal artifacts, as well as his paintings of the Far West-had long-range effects on an emerging generation of French writers and artists (1-28). Framing his analysis in terms of alterity, Fabre posited that the sudden appearance of the Musée de l'Indien constituted an "eye-opening" exposure to "the Other," which became a key component in the development of European Modernism (5). The brilliant colors of the Iowas' clothing and body art, the frenetic dynamism of their dancing, and the alien dissonance of their music, brought on a "simultaneous disorientation" of hearing and sight (7), while the thousands of "bizarre and frightening" objects exhibited through the rooms further destabilized the viewers' grasp on the here and now. 
Figure 12

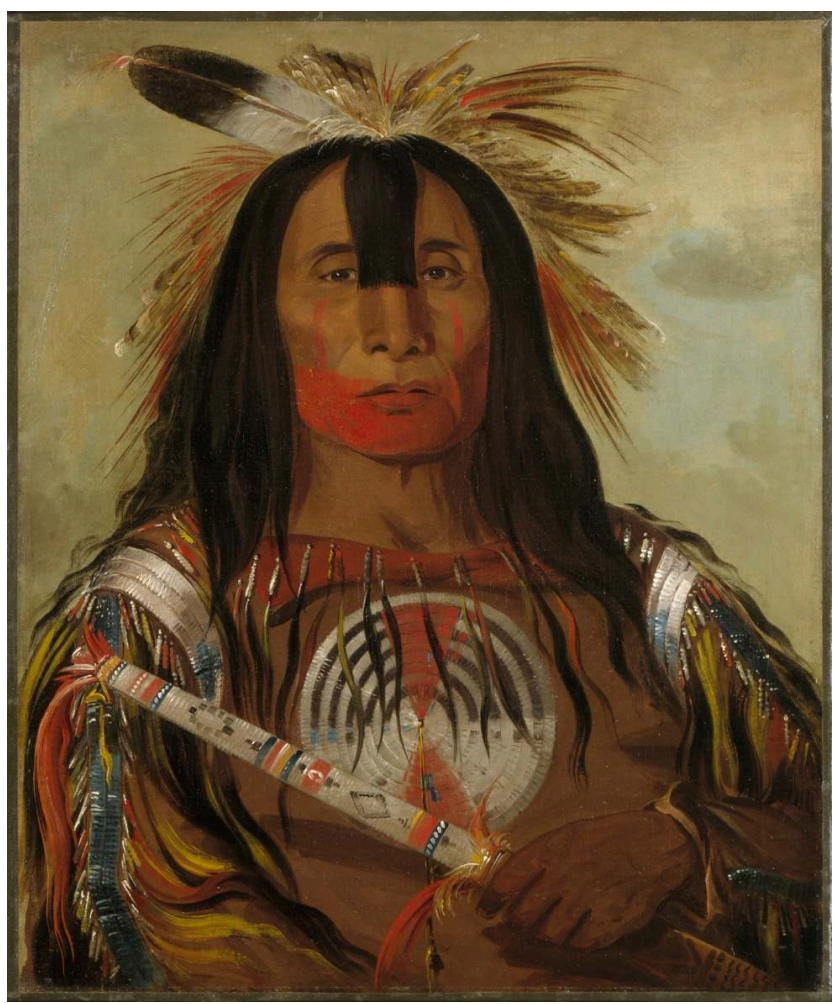

George Catlin, Portrait of Stu-mick-o-súcks (Buffalo Bull's Back Fat), 1832. Oil on canvas, 29 × 24 in., Smithsonian American Art Museum, Gift of Mrs. Joseph Harrison, Jr. Washington, DC/Art Resource, NY.

Fabre also considered the reception and impact of Catlin's art-the hundreds of paintings in the Musée de l'Indien, as well as the two works that were accepted into the Salon of 1846 (1-28): "Shon-ta-y-e-ga (petit loup), guerrier Ioway, peau rouge de l'Amérique du Nord" (Figure 4) and "Stu-mich-o-sucks, (la graisse du dos du buffalo), chef suprême de la tribu des pieds noirs, peau rouge de l'Amérique du Nord" (Explication 41, no. 314, 315) (Figure 12). Running through the critical reactions of Théophile Gautier, Théophile Thoré, Champfleury, Sand, and Charles Baudelaire are such concepts as freshness, spontaneity, sincerity, naïveté, simplicity, and savagery. About Catlin's paintings, Gautier wrote that "[f]or the most part they are sketches ("pochades"), with the backgrounds barely covered; but nothing characteristic has been omitted, however rapidly the work was done; an artist of more talent would perhaps have achieved much less. Living in "a worn-out world," he welcomed the "freshness" and singularity of Catlin's landscapes (1845 1-2). ${ }^{22}$ As Thoré interpreted his technique: "M. Catlin paints peacefully with spontaneity, placing one accurate and fresh ("franc") tone beside another, and he does not seem to go back with either glazes or impasto. But his feeling is so alive and in a way so sincere, his execution so naïve and so spontaneous, that the effect, seen correctly, is rendered correctly" (1845 1). Champfleury preferred Catlin's Salon entries to the unremittingly mediocre likenesses one usually saw, and he opined that Catlin's work looked particularly impressive among the other Salon paintings: "In the Louvre, these portraits immediately acquire a strange appearance. The heads are painted simply, cruelly even, with savagery. But make no mistake. M. Catlin is not a pure innocent ("une nature vierge") when it comes to painting" (1894 54). ${ }^{23}$ 

of contemporary academic art. In Le Constitutionnel on June 22, 1845, Thoré saw Catlin's unconventional paintings as free of what he termed "the scabrous methods of civilized art" (1). Sand estimated that "every artist will recognize in his paintings a naif talent, and [...] this something felt and understood that no one can acquire if he is not gifted with it, and that no coldly acquired theory can ever replace" (Sand, 1846 188). In his review of the 1846 Salon, Baudelaire introduced a section on color with references to the deceptive simplicity of Catlin's paintings and suggested "that what has misled the public and the journalists regarding M. Catlin, is that he does not do the bravura ("crâne") painting, to which all our young people have become so accustomed that it is now the classic way to paint" (Baudelaire 446).

, encounter with Catlin's "museum spectacle" and his paintings provided "an unexpected inspiration for the construction of a new aesthetic, in which 'the other in art,' that is, all forms of creation a priori excluded from the academic domain, played a major role" (27-28). To the "Catlin effect" would later be joined "the intense 'estrangement' of 'popular art"' (4), and in The Painter's Studio, his "tableau-manifeste," Courbet would recollect and celebrate the search for a modernist aesthetic that Catlin's works had sparked ten years before (13). At pains to connect Courbet with Catlin, and solidify the idea that the latter's museum and art work had contributed to the formation of French modernism, Fabre singled out the figure of the boy drawing on the floor in The Painter's Studio and deemed that it "irresistibly evokes" a figure mentioned by Sand during her private visits with Iowas (13). On one occasion, she noticed the young Wa-ta-we-bu-ka-na, who was sketching in the Iowas' quarters: "Lying flat on his chest, his head enveloped in his blanket, as the Arabs and Indians do when they want to gather their thoughts, he draws on the floor the faces of people he has just seen" (202). The particularities of Sand's description are so striking-a young boy, lying face down on the floor and drawing people around him-that I had had the same reaction as Fabre and immediately connected Sand's description of Wa-ta-we-bu-ka-na with the similarly prone and engaged young boy that Courbet depicted on the righthand side of The Painter's Studio (Figures 1 and 13).

As Courbet has placed the figure, it forms part of a foreground quintet that includes Champfleury (seated just to the boy's right); the woman with the brightly colored shawl and her companion (above and to boy's left); and the figure of the book-reading Baudelaire (at the painting's right edge) (Figure 13). Fabre has interpreted the shawlclad woman as an "allegorized" portrait of Sand (13), and although this may or may not be the case, I find appealing the idea that here, once again, Courbet might be playing with the viewer's perceptions, sending out tantalizing and hard-to-prove clues, this time as to the female figure's identity. In 2018, I photographed the detail of the young boy from the newly cleaned canvas in the Musée d'Orsay (Figure 14). While the figure has long been characterized as drawing a stick figure (Toussaint 260), it can now be seen to resemble a simplified sketch of a Native American. The figure's head is smudged with a black band across the top, as in Catlin's portrait of Mew-hew-she-kaw (Figure 5). Above the band appear the traces of a feather or two, and the stick figure's body has been covered with a tunic-like patch of light brown. Thus, it is possible that the young boy, or the young boy along with the "allegorized" figure of Sand, might reference Sand's "Relation d'un voyage" and, thus, imply an awareness on Courbet's part of 
Catlin's Museum and his art. If that conjecture is too murky or insubstantial, there is another avenue of connection worth discussing in this respect.

Figure 13

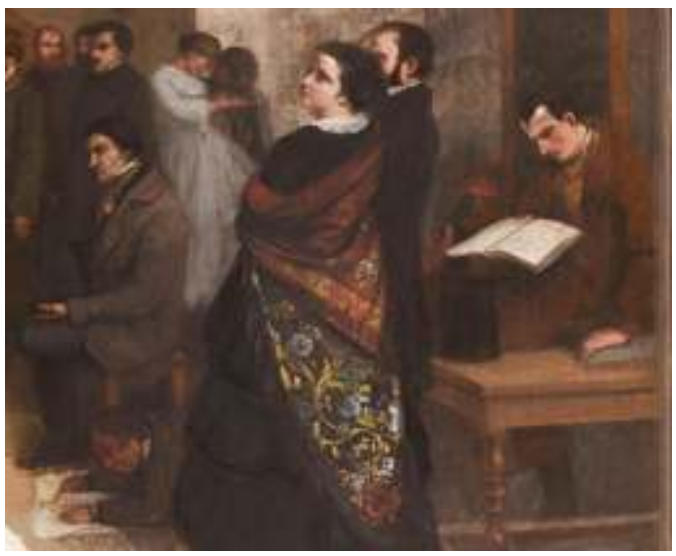

Courbet, Detail of right side of The Painter's Studio, 1854-1855.

Figure 14

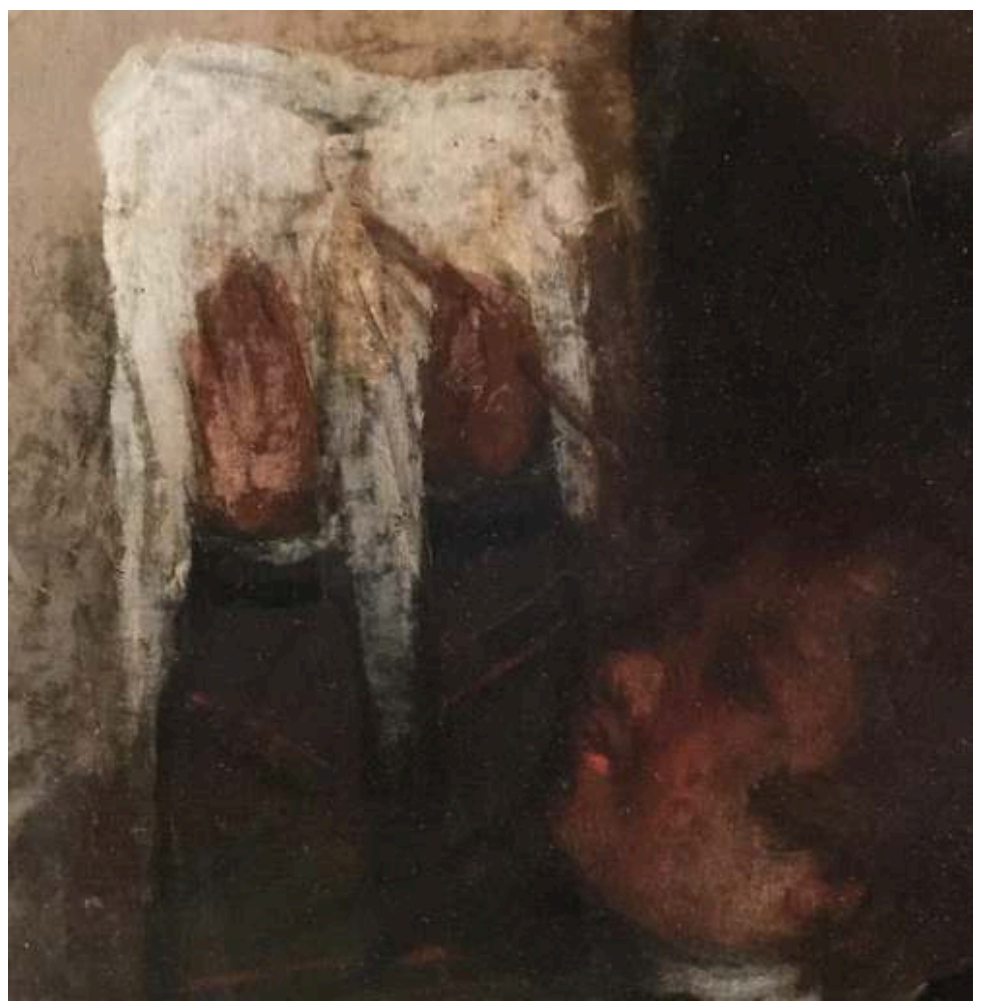

Courbet, Detail of the young boy (rotated right). Photograph Taken by the Author.

The years 1845 and 1846 were a period of searching and ultimately discouragement for Courbet. ${ }^{24}$ Up until then, he had had a lackluster showing at the Salon: he had been refused outright in 1841,1842, and 1843 and had managed to get only one work (out of three) accepted in 1844 and one (out of five) in 1845 (Courbet 22-26). He had placed great hopes in his submissions to the Salon of 1846, but although he sent eight paintings to the jury, seven of them were turned down. The one work accepted was a 
Portrait of $M^{* * *}$, which is thought to have been the painting now known as The Man with the Leather Belt (Courbet 25-26). His correspondence shows that he was disheartened by the rejections and at a loss to know what to do next (Courbet 60-61). In a letter to the art critic Gautier, Courbet complained about his negligible showing at the Salon and asked for advice: "after nearly seven years of painting my way through the labyrinth of all the schools, not having had anything except my feeling as teacher and guide, I am especially eager to know where I stand and where my efforts have led me" (Courbet 61). Though Courbet was hoping for an assessment of his work, the eminent Gautier never tendered a reply (Courbet 61, n. 3).

30 Courbet's letters also show that he was following newspaper reviews in spring 1846, hoping that his Portrait of $M^{* * *}$ would attract the attention of the press (Courbet 60). Several newspapers had promised to write about him, but did not (Courbet 60), and while Courbet was scouring the daily papers for his own name, he must surely have stumbled upon the laudatory comments written about Catlin's Salon paintings. Particularly galling perhaps were the reviews by his friends Champfleury and Baudelaire, who praised Catlin's work, but wrote not a single line about the Portrait of $M^{* * *}$. If Courbet had managed to ignore the presence of Catlin and his Indian museum in 1845 , which is difficult to imagine, he could hardly have avoided coming across the American painter and his work at the time of the 1846 Salon.

Figure 15

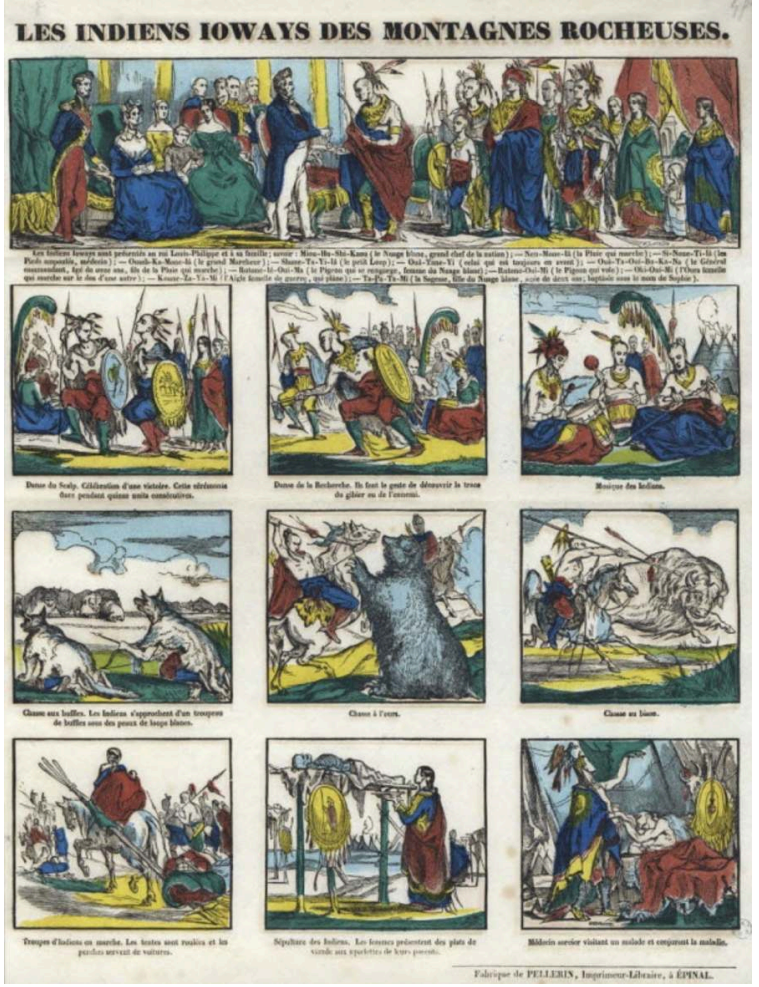

Les Indiens loways des Montagnes Rocheuses, 1846. Image d'Épinal, Musée des Civilisations de l'Europe et de la Méditerranée.

31 The connections between Catlin and Courbet may extend to the composition of The Painter's Studio. Little has been written about images that might have informed its composition, probably because the apparently random sprawl of the figures seems to 
preclude the idea that antecedents could exist. And yet in crucial respects the painting recalls the upper register of The Iowa Indians from the Rocky Mountains (Figure 15), an image d'Épinal that commemorates the Iowas' receipt of medals from Louis Philippe. The similarities between the folk-art print and Courbet's The Painter's Studio consist of the extremely horizontal format of both works, the prominence and pose of the figure right of center, and the general distribution of the crowd of seated and standing figures. In his extensive study of the Les Indiens Ioways, Frédéric Maguet has signaled the print as an exceptional work, which marked a revolutionary departure from JeanCharles Pellerin's standard productions: "If one has in mind the classic Épinal production, everything is new in this print: the disposition, the theme, the treatment and the sources" (13). Steeped in a knowledge of Catlin's paintings and of the Iowas' stay in Paris, the print was highly innovative in its division into a banner image at the top and multiple cells beneath and in its depiction of a contemporary event, which provided "imagistic reporting in the modern sense of the term" (Maguet 14). Published in early 1846 and destined for an unusually large public, Les Ioway Indians was issued in an edition of five thousand (Maguet 15).

The influence of popular prints on Courbet's paintings has been solidly established by the now-classic studies of Meyer Schapiro (1978) and Linda Nochlin (1965, 1967, 1976). In the late 1840s, the art of the people found a receptive audience among the French artists and writers, particularly those of Courbet's immediate circle. Folk art in the form of prints, music, poetry, and fiction was seen to embody vitality and authenticity and to offer a salutary alternative to the period's mainstream visual and literary arts. Among the friends and influences Courbet situated on the righthand side of The Painter's Studio, Max Buchon had a great interest in rustic tales and song lyrics, and Champfleury had begun to collect popular prints..$^{25}$ All through the period represented in The Painter's Studio-that is, the seven years from 1848 to 1855-Courbet had drawn upon specific folk images, including images d'Épinal, for his compositions and subject matter, and the trend continued into the later years. That the composition of The Painter's Studio clearly resembles the upper register of The Ioway Indians thus accords with the pictorial strategies Courbet employed before and after the painting's conception. The compositional resemblances further suggest that this painting that commemorates the shift in Courbet's art that began in 1848-the shift stimulated by anti-academic peoples' art-was itself based upon a folk image, and one that was similarly both naïve and groundbreakingly modern.

\section{Conclusion: Back to the Beginning}

There remain several issues to address before I bring this essay to a close. The first concerns the importance of the figures of Hercules and the queue-rouge within the iconography of Courbet's The Painter's Studio. If they do represent the exploitation of Native Americans, then the identification amounts to more than the addition of a minor art-historical detail. Rather, these two backgrounded and seemingly insignificant figures could reference the millions of Native Americans who were exterminated in the United States, as well as the deplorable commercialism that had brought the Iowas and Ojibwas to Paris, degraded them in the Salle Valentino, and resulted in ten more deaths. Thus, the figures of Hercules and the queue-rouge deepen 
the gravity of the painting's left side, freighting it with the weight of all those Native Americans who had lost their lives to the white man's oppression and greed.

In his treatment of the Native Americans "exhibited" in his Indian Museum, Catlin cannot be relieved of responsibility for the tragedies that occurred. He was an individual of deeply conflicted interests, and personal motivations often trumped altruistic concerns. Though the creation of his museum stemmed in part from "devotion to the Indian cause" (Dippie, 2002 54), he was also an opportunistic showman bent on making a profit and an intensely ambitious painter willing to use Native Americans to promote his own art. (Reddin, 1999 4-6). ${ }^{26}$ After the deaths of the Iowas in his troupe-the infant Corsair, No-ho-mun-ya, and O-kee-wee-me-Catlin seems to have disassociated himself from culpability and merely incorporated more Native Americans -the newly arrived Ojibwas-into his show. It took seven Ojibwa deaths to put an end to Catlin's enterprise.

If those paintings for which he had sacrificed Native American lives-the works shown in his museum and particularly the two exhibited at the Salon of 1846-did impact Courbet and the writers around him, then Catlin's position in the history of art becomes mind-bendingly complex: an American painter, who failed as an artist in his provincial home country, produced a large corpus of works that depict Native Americans; in Paris, he exploited Native Americans to draw attention to the paintings, which were then championed by some of the most progressive artistic talents in France and contributed to the origins of French modernism.

\section{BIBLIOGRAPHY}

Works Cited

BARNUM, P. T. The Life of P. T. Barnum, Written by Himself. London: Sampson, Low, 1855.

BARNUM, P. T. Selected Letters of P. T. Barnum. Ed. A. H. Saxon. New York: Columbia University Press, 1983.

BAUDELAIRE, Charles. Cuvres complètes. Ed. Claude Pichois, vol. 2. Paris: Gallimard, 1976.

BEETEM, Robert. “George Catlin in France: His Relationship to Delacroix and Baudelaire.” Art Quarterly, vol. 24, no. 2, summer 1961, p. 129-145.

BLAINE, Martha Royce. The Ioway Indians. Norman: University of Oklahoma Press, 1995.

CATLIN, George, Catalogue of Catlin's Indian Gallery of Portraits, Landscapes, Manners and Customs, Costumes, \&c. \&c., Collected During Seven Years' Travel Amongst Thirty-Eight Different Tribes, Speaking Different Languages. New York: Piercy \& Reed, 1837. library.metmuseum.org/record=b1104502. Accessed 20 April 2017.

---. Letters and Notes on the Manners and Customs of the North American Indians, 2 vols. London, Published by the Author at the Egyptian Hall, Piccadilly, 1841. Reprint 1995. North Dighton, MA: JG Press. 
---. North American Indian Portfolio: Hunting Scenes and Amusements of the Rocky Mountains and Prairies. London: Published by the Author at the Egyptian Hall, Piccadilly, 1844.

---. Notes of Eight Years' Travels and Residence in Europe with His North American Indian Collection, $3^{\text {rd }}$ ed. 2 vols. London, Published by the Author at His Indian Collection, 1848.

---. Notice sur les Indiens Ioways et sur le Nuage Blanc, $1^{\text {er }}$ Chef de la tribu, venus des plaines du HautMissouri, près des Montagnes Rocheuses (territoire des États-Unis, Amérique du Nord), sous la conduit de G. H. C. Melody. Paris: Imprimerie de Wittersheim, 1845. catalog.hathitrust.org/Record/100272865. Accessed 11 March 2019.

CHAMPFLEURY. “Salon de 1846."CEuvres posthumes de Champfleury-Salons 1846-1851. Preface by Jules Troubat. Paris: Alphonse Lemerre, 1894, p. 3-82.

---. Histoire de l'Imagerie populaire. Paris: E. Dentu, 1869.

CHU, Petra-ten-Doesschate. The Most Arrogant Man in France. Princeton: Princeton University Press, 2007.

CLARK, T. J. Image of the People: Gustave Courbet and the 1848 Revolution. Berkeley: University of California Press, 1999.

CONN, Steven. History's Shadow: Native Americans and Historical Consciousness in the Nineteenth Century. Chicago: University of Chicago Press, 2004.

COOPER, James Fenimore. The Last of the Mohicans. 1826. Introduction and notes by Stephen Railton. New York: Barnes \& Noble, 2003.

COURBET, Gustave. Letters of Gustave Courbet. Ed. and Translated by Petra ten-Doesschate Chu. Chicago: University of Chicago Press, 1992. French edition: Correspondance de Courbet, Paris, Flammarion, 1996.

DIPPIE, Brian W. The Vanishing American: White Attitudes and U.S. Indian Policy. Middletown, CT: Wesleyan University Press, 1985.

---. Catlin and His Contemporaries: The Politics of Patronage. Lincoln: University of Nebraska Press, 1990.

---."Green Fields and Red Men," George Catlin and His Indian Gallery. Eds. George Gurney and Therese Thau Heyman. Washington, DC: Smithsonian American Art Museum, 2002, p. 26-61.

DUNLAP, William. History of the Rise and Progress of the Arts of Design in the United States, 3 vols. New York: George P. Scott, 1834.

EISLER, Benita. The Red Man's Bones: George Catlin, Artist and Showman. New York: W. W. Norton, 2013.

ELLIOTT, Kate. "Reclaiming the Land, Reclaiming the Indian: The La Salle Series of George Catlin," American Nineteenth-Century History, vol. 15, 2014, p. 237-261. doi.org/ 10.1080/14664658.2014.961338. Accessed 5 April 2018.

Explication des ouvrages de peinture, sculpture, architecture, gravure, et lithographie des artistes vivants [Salon livret]. Paris: Vinchon, 1846.

FABRE, Daniel. “L'Effet Catlin; Paris, 1845-46." Gradhiva, vol. 3, 2006, p. 1-28. gradhiva.revues.org/ 194. Accessed 17 April 2017.

FRIED, Michael. Courbet's Realism. Chicago, University of Chicago Press, 1990.

Gustave Courbet (1819-1877). Paris: Éditions des musées nationaux, 1977. 
GAUTIER, Théophile, “Les Indiens Ioways," La Presse, $10^{\text {ème }}$ année, numéro 3308, p. 1-2.

HERDING, Klaus. Courbet: To Venture Independence. Translated from the German by John William Gabriel. New Haven: Yale University Press, 1991.

HOFMANN, Werner. L'Atelier de Courbet. Translated from the German by Jean Torrent. Paris: Éditions Macula, 2018.

HORTON, Jessica. “Ojibwa Tableaux Vivants: George Catlin, Robert Houle, and Transcultural Materialism.” Art History, vol. 39, 2016, p. 124-151.

Le Salon caricatural: Critique en vers et contre tous. Paris: Charpentier, 1846. Also reprinted in Baudelaire 1976, p. 501-524.

L'Illustration, journal universel, 26 avril 1845, vol. 5, no. 115, p. 129-130.

LITTRÉ, Émile. Dictionnaire de la langue française, vol. 2. Paris: Hachette, 1874.

LOUIS PHILIPPE. Diary of My Travels in America. Translated from the French by Stephen Becker. New York: Delacorte Press, 1977.

LUBBERS, Karl. "Strategies of Appropriating the West: The Evidence of Indian Peace Medals." American Art, vol. 8, no. 3-4, 1994, p. 79-95.

MAGUET, Frédéric. “Des Indiens de papier.” Gradhiva, vol. 3, 2006, p. 1-20, gradhiva.revues.org/ 225. Accessed 17 April 2017.

MAUNGWUDAUS. "Compte rendu des Indiens Chippewas qui ont voyagé parmi les Blancs (1848)." Gradhiva, vol. 3, 2006, p. 1-11, gradhiva.revues.org/246. Accessed 17 April 2017.

---. An Account of the Chippewa Indians, Who Have Been Travelling among the Whites. London: British Library, 2011.

MULVEY, Christopher, “George Catlin in Europe." In George Catlin and His Indian Gallery. Eds. George Gurney and Therese Thau Heyman. Washington, DC: Smithsonian American Art Museum, 2002, p. 62-91.

NICOLSON, Benedict. Courbet: The Painter's Studio. London, Allen Lane: 1973.

NOCHLIN, Linda. "Innovation and Tradition in Courbet's A Burial at Ornans." 1965. Reprinted in Linda Nochlin, Courbet. London: Thames \& Hudson, 2007, p. 19-28.

---. "Courbet's Meeting: A Portrait of the Artist as a Wandering Jew." Art Bulletin, vol. 49, no. 3, September 1967, p. 209-222.

---. The Development and Nature of Realism in the Work of Gustave Courbet: A Study of the Style and Its Social and Artistic Background. New York: Garland, 1976.

“Nouvelles et faits divers." La Presse, June 14, 1845, $10^{\text {ème }}$ année, no. 3334, p. 3.

“Nouvelles et faits divers." La Presse, June 15, 1845, $10^{\text {ème }}$ année, no. 3335, p. 3.

REDDIN, Paul. Wild West Shows. Urbana: University of Illinois Press, 1999.

RIAT, Georges. Gustave Courbet: Peintre. Paris: H. Floury, 1906.

RUBIN, James H. Courbet. London: Phaidon Press, 1997.

SAND, George. "Relation d'un voyage chez les sauvages de Paris." Le Diable à Paris-Paris et les parisiens, vol. 2, 1845. Reprinted Paris: Hetzel, 1846.

SAND, Maurice. Masques et bouffons (Comédie italienne), vol. 1, Paris: Michel Lévy Frères, 1860. 
SAXON, A. H. P. T. Barnum: The Legend and the Man. New York: Columbia University Press, 1989.

SCHAPIRO, Meyer. “Courbet and Popular Imagery: An Essay on Realism and Naïveté.” 1941. Reprinted in Modern Art: 19th and 20th Centuries. New York: George Braziller, 1978, p. 47-85.

SÉRULLAZ, Arlette, and Claude Macherel. "Quand Delacroix croqua-t-il des Ojibwas?” Gradhiva, vol. 3, 2006, p. 1-6, gradhiva.revues.org/239. Accessed 1 May 2017.

SILVESTRE, Théophile. “Courbet." Histoire des artistes vivants français et étrangers: Études d'après nature. Paris: E. Blanchard, 1856.

THORÉ, Théophile, “Revue des arts.” Le Constitutionnel, 22 June 1845, no. 175, p. 1.

THOMSON, Richard. Seurat's Circus Sideshow. New York: Metropolitan Museum of Art, 2017.

TOCQUEVILLE, Alexis de. Democracy in America. vol. 1. 1835. Ed. J. P. Mayer. Translated from the French by George Lawrence. New York: Harper \& Row, 1969.

TOUSSAINT, Hélène. “Le dossier de 'L’Atelier' de Courbet.” in Gustave Courbet (1819-1877), Paris : Éditions des musées nationaux, 1977, p. 241-272.

TRUETTNER, William H. The Natural Man Observed: A Study of Catlin's Indian Gallery. Washington, DC: Smithsonian Institution Press, 1979.

\section{NOTES}

1. I extend my thanks to Emily C. Burns and Cécile Roudeau, for their invaluable contributions to the writing of this essay, and I gratefully give further credit to Isolde Pludermacher (Conservateur peinture, Musée d'Orsay), Helena Patsiamanis (Bibliothèque de la Conservation, Musée d'Orsay), Cécile Bringuier (Restauratrice de peintures, Musée d'Orsay), Angèle Martin (Médiathèque d'étude et de recherche, Musée du Quai Branly-Jacques Chirac), Marjorie Munsterberg, and Joyce Faust for their help and support at crucial phases of this project. All translations from French to English are my own.

Key writings on the work include Nicolson; Toussaint; Nochlin, 1988; Fried 148-186; Herding 44-61; Rubin 133-154, Chu 102-107, and Hofmann. For a historiographic overview, see Fried 157.

2. He suffered from hemorrhoids for much of his life, first mentioned in a letter written to his parents in 1839 (Courbet 30).

3. Riat signaled the figure of "la paillasse"- saltimbanque or clown-but omitted mention of Hercules (126). Nicolson referred to the figures as "a fairground strong man" and a "clown-both picturesque figures, drawing their pitiful wages from the itinerant fairs" (35). Their attention directed elsewhere, Nochlin, 1988 and Fried refrain from mentioning either figure, though Fried slipped them into an inclusive terminal phrase-“a Jew, a curé, a veteran of 1793, a huntsman, an undertaker's mute, and so on" (157). Herding dubbed the figures "a carnival strongman" and "a jester" and limited his discussion to a refutation of Toussaint's interpretation of them (47). Rubin reiterated Toussaint's interpretations (144), as did Hofmann (35). Chu mentioned the clown and questioned the general validity of Toussaint's program $(102,104)$.

4. Though the opening is sometimes placed at the beginning of June, Daniel Fabre clarified that it occurred at the end of the previous month (9). Key readings on Catlin's sojourn in Paris include Truettner 46-53, Dippie, 1990 105-109, Reddin 43-47, Mulvey 71-75, Eisler 319-352, and the entire issue of Gradhiva, which was devoted to the Paris showing of Catlin's Museum.

5. Through his career, Catlin continually published book-length accounts of his travels and paintings $(1837 ; 1841 ; 1844 ; 1848)$. 
6. The term "tableaux vivans" is the one Catlin used to describe these re-enactments, though it usually refers to silent, static presentations. For an analysis of Catlin's tableaux vivants from the standpoint of transcultural materialism and recent work by the contemporary Native American artist Robert Houle, see Horton.

7. Barnum showcased such wonders as "a Fejee Mermaid," which had been fabricated from a monkey's head sewn to the body of a fish; and Joice Heth, a woman said to be 161 years old and the former nursemaid of George Washington (Barnum, 1855 148-76; 230-242).

8. After the tragic experiences of the Osages in Paris the late 1820s, the United States government had banned Native Americans from traveling abroad "on speculation"-that is to say, without the assurance of funding for their stay and for their trip home.

9. Because Catlin's accounts of his trips with Native Americans remain the only source of the tribe members' names, I have retained his phonetic spellings and punctuation.

10. Girardet was court painter to Louis Philippe and the painting was commissioned by the king.

11. The periodical was aimed at a culturally progressive readership. It featured texts by Sand, Honoré de Balzac, Henry Monnier, Stendhal, Alfred de Musset, Charles Nodier, Gérard de Nerval, and Eugène Sue, among others, and it had illustrations by the fashionable caricaturist Gavarni. The publisher was Jules Hetzel, a man of liberal politics who would serve in various ministries under the Second Republic. Hetzel reprinted the second volume of Le Diable à Paris (which contains Sand's essay) under the title Le Tiroir du diable.

12. Sand's population figures must be taken with reservation. In the introduction to The Vanishing American, Brian Dippie has stressed the impossibility of securing firm numbers for Native American populations before and during the nineteenth century. Because of subjective factors that affected tribal approximations, "all estimates are necessarily relative rather than absolute" (1985 xvii). However, given the epidemics that stuck Native Americans in the late 1830s, the recent loss of life among the Iowas would have been substantial (Dippie, 1985 36-38).

13. By the time of Sand's essay, the Iowas had been moved from the Hotel Victoria to rooms in the Salle Valentino.

14. Though a tomb monument by Auguste Préault was planned for her grave, the project was never realized.

15. During the stay in Paris, Uh-wus-sig-gee-zigh-gook-kway (Woman of the Upper World) gave birth to a "pappoose" (Catlin, 1848 vol. 2 280), so though five Ojibwas actually returned, only four were survivors of the original group.

16. For an explanation of the term saltimbanque in nineteenth-century France and an analysis of images in which this figure appears, see Thomson 22-40.

17. The term was used in the "Causeries" published in 1846, in Le Tintamarre, a joint publication by Baudelaire, Théodore Banville, and Auguste Vitu (www.cnrtl.fr/definition/bhvf/queue-rouge Accessed 20 April 2017).

18. When Catlin exhibited two of his portraits of Native Americans in Paris in 1846, each carried the term "peau-rouge" in its subtitle.

19. The skin tone may also signify other oppressed peoples in the United States, such as AfricanAmericans who remained enslaved by law at the time Courbet painted L'Atelier. See Tocqueville's analysis of America as a tri-racial nation (Tocqueville 316-407; Conn 2).

20. As described in the Pléiade edition of Baudelaire's writings, the image of the dog in a folded paper hat satirizes a painting by Alexandre-Gabriel Lebaillif (Baudelaire 506; 1332). The Salon caricatural de 1846 was another joint production of Baudelaire, Théodore Banville, and Auguste Vitu, and because several artists worked on the illustrations, it is impossible to determine the caricature's creator (Baudelaire 1326-1328).

21. Shon-ta-yi-ga's receipt of the Tyler medal is described at length in Sand, 1846 202-203. In The Last of the Mohicans, James Fenimore Cooper alluded to these medals, and his notes to the novel explain their purpose: "It has long been a practice with the whites to conciliate the important 
men of the Indians, by presenting medals, which are worn in place of their rude ornaments. Those given by the English generally bear the impression of the reigning king, and those given by the Americans that of the president" (95 and 370, n. 1). Initiated during George Washington's term in office, these seemingly honorific awards were meant to inculcate a Native-American identity forged on submissiveness to white culture (Lubbers).

22. In this paragraph and the following, I have drawn on the writers discussed by Fabre, returned to the original texts, and translated their remarks for an Anglophone audience.

23. In 1846, the Salon was installed in the Louvre, as it had traditionally been.

24. T. J. Clark characterized Courbet as "flailing about" and "foraging" during these years $(42,43)$ and offered the drubbing assessment of "what a bad, and what an ordinary painter Courbet was when he began" (39).

25. Champfleury would later publish a history of the popular print (1869).

26. On Catlin's character and his attitudes toward Native Americans, see also Dippie, 1990 21; Dippie, 2002 54; Mulvey 64-65; Eisler 310.

\section{ABSTRACTS}

This essay interrogates connections between Gustave Courbet's The Painter's Studio (1855; Musée d'Orsay) and the visual culture of American Indian performance in Paris. The article builds evidence from visual analysis and from reviews of George Catlin's American Indian Gallery (Paris, 1845) written by George Sand, Charles Baudelaire and others. The article speculates on the resonance between Courbet's disenfranchised figures and colonial realities implied by Catlin's display. It also connects reactions to Catlin's museum with the burgeoning of modernism in midnineteenth-century France and with the transformation in Courbet's painting during the years marked by The Painter's Studio.

Cet essai revient sur le célèbre tableau de Gustave Courbet, L'Atelier du peintre (1855, Musée d'Orsay) et le lit à la lumière de la culture des performances amérindiennes à Paris à la même époque. Pour ce faire, l'article s'appuie sur l'analyse du tableau lui-même et des comptes rendus de la Galerie indienne de George Catlin (présentée à Paris en 1845) sous la plume de George Sand, de Charles Baudelaire, entre autres. Les figures affranchies que l'on voit dans le tableau, l'article suggère, font écho à la réalité de la colonisation de peuplement qui sous-tend la Galerie indienne. Les réactions à cet événement sont aussi relues à l'aune des débuts du modernisme au milieu du XIXe en France et en lien avec la transformation de la peinture de Courbet dans ces mêmes années.

\section{INDEX}

Mots-clés: George Catlin, Gustave Courbet, Iowa, Ojibwa, performance amérindienne, George Sand, saltimbanque, colonisation de peuplement, P.T. Barnum, Salon de 1846

Keywords: George Catlin, Gustave Courbet, Iowa, Ojibwa, Native American performance, George Sand, saltimbanque, settler colonialism, P.T. Barnum, the Salon of 1846 
AUTHOR

JANE M. ROOS

Hunter College and The Graduate Center of CUNY

Jmroos@aol.com 